\title{
An Assessment of Available Water for Livestock and Garden Irrigation in Dry Season for Subsistence Farmers in Zimba District
}

\author{
Chomba Innocent. C \\ *Corresponding Author: Chomba Innocent. C, Ministry of Water Development, Sanitation and \\ Environmental Protection, Zimba District
}

\begin{abstract}
Zambia's rural food security and human development depend enormously on subsistence agriculture. Agriculture determines food availability, the first link in the food security chain. The aim of this study was to assess the water available for livestock and garden irrigation in dry Season for six selected water points (dams) used for garden irrigation and livestock watering in Zimba District. The study revealed that the total number of livestock that drink from the six selected water points is 11,850. The total area under garden irrigation is 8.1 hectares. The estimated total water volume in the dams at full capacity was $207,478.70 \mathrm{~m}^{3}$. The total water available for livestock and irrigation after taking into consideration evaporation and seepage from the dams is $52,189.50 \mathrm{~m}^{3}$. While the combined water needed for livestock and garden irrigation in dry season is $112,893.12 \mathrm{~m}^{3}$. This means there is an approximately water deficit of about $60,703.62 \mathrm{~m}^{3}$. This is has a result of combination of factors such as, limited reservoir dam facilities, sedimentation of reservoirs, increasing population of livestock and irrigation farming, climate change and variability. It is concluded that rural development in Zimba District can be slow and difficult if a water supply and availability for rural agriculture development among subsistence farmers cannot be assured in both rain season and dry season.
\end{abstract}

Keywords: Water, Food Security, Livestock, Irrigation and Sustainable Agriculture.

\section{INTRODUCTION}

Globally, $90 \%$ of the global water consumption is for agricultural purposes, and more than $40 \%$ of the crops are produced under irrigated conditions in order to support agricultural development due to increasing human population and uncertain climate. Irrigated agricultural land comprises less than a fifth of all cropped area but produces $40-45 \%$ of the world's food. It is generally expected that irrigated agriculture will have to be considerably extended in the future in order to feed growing populations (an additional 1.5-2 billion people by 2025, according to United Nations population projections). However, it is not yet known whether there will be enough water available for the necessary extension. As it is very likely that water demands of the domestic and industrial sectors will increase in the future, even regions that do not have water scarcity problems today such as Zambia, will be restricted in their agricultural development and thus possibly their food security by a lack of water availability [1].

Zambia's rural food security and human development depend enormously on agriculture. Agriculture determines food availability, the first link in the food security chain. Agriculture in Zambia provides livelihoods for about $50 \%$ of the population and $67 \%$ of formal labour force; it remains by far the main opportunity for income and employment for women who comprise $65 \%$ of the rural population. Thus, it is the main source of income and employment for a majority in Zambia, especially the poor in rural areas such as Zimba District. The importance of irrigation to rural livelihoods is highlighted globally by the fact that irrigated farmland provides $43 \%$ of global cereals production and $60 \%$ of the grain production in developing countries [2].

Zimba district is an agriculture dominated district, $85 \%$ of the Population in Zimba depend on agriculture; thus both crop and livestock for livelihood. Hence, the availability of water in right quantities for agricultural activities is of ultimate importance for the district's agricultural 
development. However, the dry seasons in Zimba are long about seven months, and dry spells during the rainy season are common feature. Additionally, Zimba district has no perennial streams. This implies that few months after the rain season and runoff, subsistence farmer depend on the available water points in small earth dams for livestock watering and garden irrigation.

Livestock keeping is an important subsector of agriculture in Zimba district. It has a cultural value among the local people and is a means for poor people to accumulate wealth. Large numbers of subsistence farmers and herders depend on livestock for their livelihoods. Livestock depend on water. Drinking water in right quantities is essential for Livestock survival and reproduction in both rain season and dry season. Currently no assessment has been done in the district to estimate the water available for livestock watering and garden irrigation in dry season. The central argument in this study is that rural development in Zimba District can be slow and difficult if a water supply and availability cannot be assured in both rain season and dry season. The aim of this study was to assess the water available for livestock and garden irrigation in dry Season for six selected water points used for gardening and livestock watering in Zimba District along the main inland roads.

\section{THE STUdy AREA}

Zimba district is located in Southern Province of Zambia, it lies between $17^{\circ}$ and $18^{\circ}$ Latitudes South and $26^{\circ}$ and $27^{\circ}$ Longitudes East. The district covers approximately a total area of $5,245.01 \mathrm{Km}^{2}$ in size (Figure 2.1). For more than a decade Zimba District and Southern Province in general has suffered a reduction in rainfall, which has impacted on farming, nutrition, surface water, groundwater supplies and the economy in general. Zimba District has an average annual rainfall of about $700 \mathrm{~mm}$, and suffers from water shortages and droughts. Surface water is the main sources of water in the district. However, all the inland streams are non- perennial as such the only way water is being harvested in dry season for livestock and agriculture is through the use of small earth dams [3].

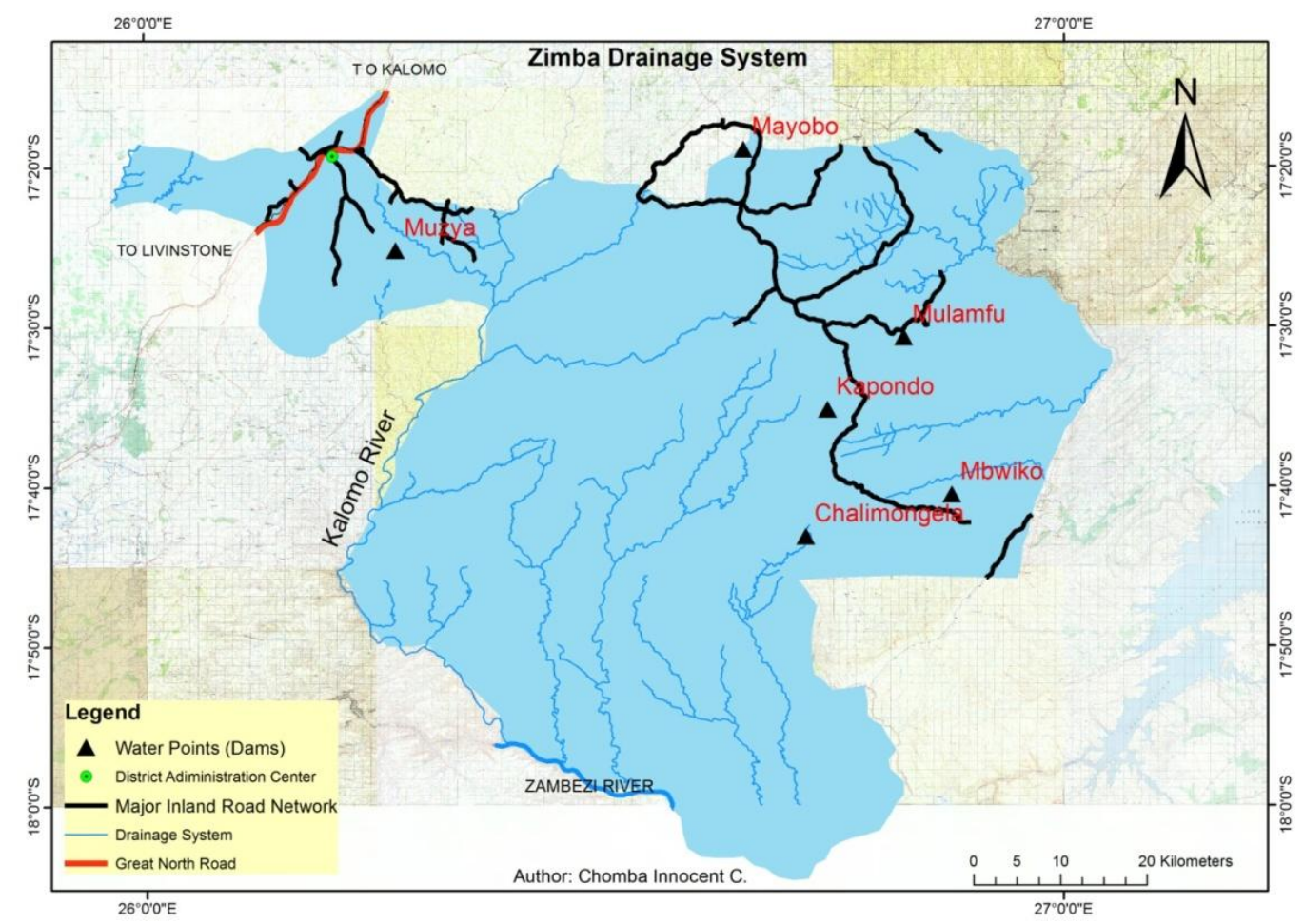

Figure2.1. Zimba Drainage System and Selected Water points for livestock watering and garden irrigation.

\section{METHODOLOGY}

Field survey and measurements were conducted for six purposively selected water points with respect to small earth dams for livestock watering and garden irrigation. The six selected water points for this study were those located near the main inland roads for easy accessibility by the researcher namely; Kapondo dam, Chalimongela dam, Mbwiko dam, Mayobo dam, Muzya dam and Mulamfu dam (Figure 2.1). Small earth dams in Zambia are a common feature as a source of water for livestock 
An Assessment of Available Water for Livestock and Garden Irrigation in Dry Season for Subsistence Farmers in Zimba District

watering and irrigation in rural areas [4]. Position System (GPS) was uses to log the location of the water points. While a questionnaire was used to assess the number of livestock in the two studies villages through the key informants (Village Headmen). The area under irrigated agriculture was measured using a measuring tape at each irrigation plot and a Geographical Position System (GPS). Bathymetric surveys (reservoir depth measurements) were also conducted for the dams in order to estimate the dam reservoir volume. The reservoir water storage volume and surface area were calculated for each reservoir using bathymetric data in ArcGIS 10.1, 3D, Area and Volume Spatial Analyst tools. The water requirement for livestock was computed using Table 1 adopted from NissenPetersen [5] and water requirement for irrigated agriculture was computed using Table 2 adopted from Kenya Agriculture Research Institute Handbook No.22) with modification to suite Zambia's circumstances.

Table1. Computing Water Requirements for Livestock

\begin{tabular}{|c|c|c|c|c|}
\hline $\begin{array}{c}\text { Type of } \\
\text { Livestock }\end{array}$ & $\begin{array}{c}\text { Number of } \\
\text { Livestock }\end{array}$ & $\begin{array}{c}\text { Daily Consumption } \\
\text { (litres) }\end{array}$ & $\begin{array}{c}\text { Number of Days } \\
\text { without Rain and } \\
\text { runoff }\end{array}$ & $\begin{array}{c}\text { Total water } \\
\text { Requirement } \\
\text { (litres) }\end{array}$ \\
\hline Cattle & Y & 50 & 150 & $\mathrm{X}$ \\
\hline Sheep & Y & 5 & 150 & $\mathrm{X}$ \\
\hline Goats & $\mathrm{Y}$ & 3 & 150 & $\mathrm{X}$ \\
\hline Pigs & $\mathrm{Y}$ & 10 & 150 & $\mathrm{X}$ \\
\hline \multicolumn{4}{r}{} \\
\hline
\end{tabular}

Table2. Computing Water Requirement for Vegetable Irrigation

\begin{tabular}{|c|c|c|}
\hline Type of Irrigation & $\begin{array}{c}\text { Vegetables Daily water Requirement for 90 } \\
\text { days on a 1/4 acre(approx.1000 m2) }\end{array}$ & $\begin{array}{c}\text { Total Water } \\
\text { Requirement (litres) }\end{array}$ \\
\hline Drip Irrigation & Vegetables & 90,000 \\
\hline Bucket Irrigation & Vegetables & 180,000 \\
\hline
\end{tabular}

\section{RESULTS AND DISCUSSION}

The study revealed that the total number of livestock that drink from the six selected water points is 11,850 (Table: 3.1). The type of livestock mainly comprised of cattle with few numbers of goat and sheep. As earlier mentioned, livestock keeping mostly cattle is an important subsector of agriculture in Zimba district. It has a cultural value among the local people and is a means for poor people to accumulate wealth. Large numbers of subsistence farmers and herders depend on livestock for their livelihoods. The total area under garden irrigation was 8.1 hectares (Table 3.1). Vegetable gardening was common in all the selected water points and the type of irrigation was bucket irrigation which uses water twice as compared to drip irrigation.

Table3.1. Number of Livestock and area under irrigation for the six water points

\begin{tabular}{|c|c|c|c|c|c|c|}
\hline No & $\begin{array}{c}\text { Name of the } \\
\text { Dam }\end{array}$ & $\begin{array}{c}\text { UTM X- } \\
\text { coordinate }\end{array}$ & $\begin{array}{c}\text { UTM Y- } \\
\text { coordinate }\end{array}$ & $\begin{array}{c}\text { Number of } \\
\text { Villages' Using } \\
\text { the Dam }\end{array}$ & $\begin{array}{c}\text { Number of } \\
\text { Livestock }\end{array}$ & $\begin{array}{c}\text { Area under } \\
\text { Irrigation (ha) }\end{array}$ \\
\hline 1 & Kapondo & 472759 & 8055460 & 6 & 3,400 & 2 \\
\hline 2 & Chalimongela & 470257 & 8040797 & 3 & 2,300 & 2 \\
\hline 3 & Mbwiko & 487127 & 8045663 & 4 & 1,070 & 1.1 \\
\hline 4 & Mayobo & 463000 & 8085488 & 4 & 960 & 1.2 \\
\hline 5 & Muzya & 422833 & 8073759 & 5 & 720 & 0.8 \\
\hline 6 & Mulamfu & 481577 & 8063815 & 4 & 3,400 & 1 \\
\hline & \multicolumn{7}{|c|}{ Total } & $\mathbf{2 6}$ & $\mathbf{1 1 , 8 5 0}$ & $\mathbf{8 . 1}$ \\
\hline
\end{tabular}

The estimated total water volume in the dams at full capacity was $207,478.70 \mathrm{~m}^{3}$ with those individual reservoirs ranging from $11,063.7 \mathrm{~m}^{3}$ to $82,743.0 \mathrm{~m}^{3}$. However, evaporation loss can remove up to about 2.5 metres depth of water per year from an open dam reservoir in a subtropical climates such as that experienced by Zimba District, although for a good estimate of this loss the evaporation rate in the specific location and the surface area of water must be known. However, a useful rule of thumb was applied in this study, which states that that about $50 \%$ of the water in a reservoir is lost each year to evaporation. Seepage loss is also difficult to estimate because dam 
An Assessment of Available Water for Livestock and Garden Irrigation in Dry Season for Subsistence Farmers in Zimba District

reservoirs are built of various soil types which result in varying degrees of seepage. Nevertheless, another common rule of thumb states that seepage may account for about half that of evaporation (or $25 \%$ of the water in a reservoir). On the basis of above rules of thumb, the total water available for livestock and irrigation after taking into consideration evaporation and seepage from the dams is $52,189.50 \mathrm{~m}^{3}$ (Table: 3.2 ).

Table3.2. Water Available for Livestock and Garden Irrigation

\begin{tabular}{|c|c|c|c|c|}
\hline $\begin{array}{c}\text { Name of the } \\
\text { Dam }\end{array}$ & $\begin{array}{c}\text { Estimated } \\
\text { Dam Reservoir } \\
\text { at Full } \\
\text { Capacity (m3) }\end{array}$ & $\begin{array}{c}\text { Estimated } \\
\text { Evaporation } \\
\text { from the Dam } \\
\mathbf{( 5 0 \%} \text { of full } \\
\text { capacity m3) }\end{array}$ & $\begin{array}{c}\text { Estimated Reservoir seepage } \\
\text { from the Dam (25\% of full } \\
\text { capacity m3) }\end{array}$ & $\begin{array}{c}\text { Estimated Water } \\
\text { Available for } \\
\text { Livestock and } \\
\text { Irrigation (m3) }\end{array}$ \\
\hline Kapondo & $11,063.7$ & $5,531.85$ & $2,765.93$ & $2,765.9$ \\
\hline Chalimongela & $32,813.6$ & $16,406.80$ & $8,203.40$ & $8,203.4$ \\
\hline Mbwiko & $33,054.3$ & $16,527.15$ & $8,263.58$ & $8,263.6$ \\
\hline Mayobo & $82,743.0$ & $41,071.50$ & $20,685.75$ & $20,985.8$ \\
\hline Muzya & $17,285.8$ & $8,642.90$ & $4,321.45$ & $4,321.5$ \\
\hline Mulamfu & 30,518 & $15,239.35$ & $7,629.50$ & $7,649.5$ \\
\hline Total & $\mathbf{2 0 7 , 4 7 8 . 7}$ & $\mathbf{1 0 3 , 4 1 9 . 5 5}$ & $\mathbf{5 1 , 8 6 9 . 6 1}$ & $\mathbf{5 2 , 1 8 9 . 5}$ \\
\hline
\end{tabular}

The combined water needed for livestock and garden irrigation in dry season for the six selected water points was found to be $112,893.12 \mathrm{~m}^{3}$. In comparison to the estimated water available for livestock and irrigation which is $52,189.50 \mathrm{~m}^{3}$, it means there is an approximately water deficit of about $60,703.62 \mathrm{~m}^{3}$ needed for garden irrigation and livestock watering for the six selected water points in dry season. All the water points except Mayobo had a water deficit (Table 3.2). The total calculated water deficit is has a result of combination of factors such as, limited reservoir dam facilities, as it was observed during the study, one dam was saving on average about four villages for their livestock and irrigation. Sedimentation is another factor that can be attributed to the low reservoir capacity of the dams. Most of the dams were built before 1990s except for Kapondo and Chalimongela both built in 2000. Hence, sedimentation is slowly reducing reservoir volumes. A similar study conducted in 2009 on a small reservoir constructed in 1987 at the Afaka Forest Reserve in Kaduna State in Nigeria. The study findings showed that about 35 percent of the reservoir storage capacity was covered with sediments within a period of 26 years, which was a serious problem that was undermining water uses of the dam [6]. It has been reported that reservoir sedimentation is an increasing problem in the management of Southern African water resources [7]. Other factors include increasing population of livestock, increased area under irrigation farming and climate change and climate variability.

Table3.3. Water Deficit for Livestock and Irrigation

\begin{tabular}{|c|c|c|c|c|c|}
\hline $\begin{array}{c}\text { Name of the } \\
\text { Dam }\end{array}$ & $\begin{array}{c}\text { Water } \\
\text { Requirement } \\
\text { for Livestock } \\
(\mathbf{m 3})\end{array}$ & $\begin{array}{c}\text { Water } \\
\text { Requirement } \\
\text { for Irrigation } \\
\mathbf{( m 3 )}\end{array}$ & $\begin{array}{c}\text { Water } \\
\text { Requirement } \\
\text { for Livestock } \\
\text { and Irrigation } \\
\mathbf{( m 3 )}\end{array}$ & $\begin{array}{c}\text { Estimated } \\
\text { Water } \\
\text { Available for } \\
\text { Livestock } \\
\text { and } \\
\text { Irrigation in } \\
\text { the Dams } \\
\text { (m3) }\end{array}$ & $\begin{array}{c}\text { water Deficit } \\
\text { for Livestock } \\
\text { and Irrigation } \\
(\mathbf{m 3})\end{array}$ \\
\hline Kapondo & 25,500 & $5,930.40$ & 31,430 & $2,765.90$ & $-28,664.50$ \\
\hline Chalimongela & 17,250 & $5,930.40$ & 23,180 & $8,203.40$ & $-14,977.00$ \\
\hline Mbwiko & 8,025 & $3,261.72$ & 11,287 & $8,263.60$ & $-3,023.12$ \\
\hline Mayobo & 7,200 & $3,558.24$ & 10,758 & $20,985.80$ & $+10,227.56$ \\
\hline Muzya & 5,400 & $2,372.16$ & 7,772 & $4,321.50$ & $-3,450.66$ \\
\hline Mulamfu & 25,500 & $2,965.20$ & 28,465 & $7,649.50$ & $-20,815.70$ \\
\hline Total & $\mathbf{8 8 , 8 7 5}$ & $\mathbf{2 4 , 0 1 8 . 1 2}$ & $\mathbf{1 1 2 , 8 9 3 . 1 2}$ & $\mathbf{5 2 , 1 8 9 . 5 0}$ & $\mathbf{- 6 0 , 7 0 3 . 6 2}$ \\
\hline
\end{tabular}

The observed water deficit for livestock in this study can have serious implications on the production and reproduction of livestock in Zimba district. It is argued that providing adequate water to livestock is critical for animal health and production. A 10 percent loss of body water is fatal to most species of domestic livestock. Water accounts for more than 98 percent of all molecules in the body and between 
50 and 81 percent of an animal's total body weight at maturity. Water is required for regulation of body temperature, growth, reproduction, lactation, digestion, lubrication of joints, and eyesight for livestock [8].

The water deficit in dry season in Zimba district is impeding the development of irrigated agriculture. There is need to provide adequate water throughout the dry season by eliminating water deficits and providing at least a measure of drought protection and by making water available for irrigated agricultural development among the rural communities through increased water harvesting facilities. The subsistence farmers gain from irrigation through increased employment and income, in improved security against impoverishment, from less out migration and in improved quality of life [9].

\section{CONCLUSION}

The study revealed that the total number of livestock that drink from the six selected water points was 11,850 . The total area under garden irrigation agriculture was 8.1 hectares. The estimated total water volume in the dams at full capacity was $207,478.70 \mathrm{~m}^{3}$ with those individual reservoirs ranging from $11,063.7 \mathrm{~m}^{3}$ to $82,743.0 \mathrm{~m}^{3}$. The water available for livestock and irrigation after taking into consideration evaporation and seepage from the dams is $52,189.50 \mathrm{~m}^{3}$. While the water needed for livestock and garden irrigation in dry season is $112,893.12 \mathrm{~m}^{3}$. This means there is approximately water deficit of about $60,703.62 \mathrm{~m}^{3}$. This is has a result of combination of factors such as, shortage of reservoir dam facilities as number of villages depended on a water point, sedimentation which has impacted on reservoir volumes, increasing population of livestock, increased area under irrigation farming among subsistence farmers and climate change and variability. It has to be noted that although this study was based only on six water points used for irrigation and livestock watering, the water deficit reflects a similar situation across Zimba District. And in some instances, the water deficit is even worse as some communities completely lack dam facilities and in other communities, the dams have silted up or bleached or the spillway has been eroded. It is concluded that rural development in Zimba District can be slow and difficult if a water supply and availability for agriculture development among subsistence farmers cannot be assured in both rain season and dry season.

\section{ACKNOWLEDGMENT}

I acknowledge the unfailing support I received from The Department of water Development, Department of Agriculture and Cooperatives, Department of Livestock and fisheries and the Senior Chiefs, headmen and the local people, the owners of the dams, in Zimba District. I am also indebted to Aaliyah Phelire Chomba, for playing a critical role in ensuring that this work is completed.

\section{REFERENCES}

[1] Petra Do" 11 and Stefan S. (2002). Global modelling of irrigation water requirements. Water Resources Research, Vol. 38, No. 4.pp 2-10.

[2] IWMI (2000). Water for food, nature and rural livelihoods. Colombo, International Water Management Institute: 68 .

[3] Chomba I.C. (2017). An Investigation of Groundwater Monitoring in Zimba District: Towards Sustainable Rural Groundwater Development and Management. International Journal of Research in Environmental Science. Vol.3. No.1.pp 20-25.

[4] Phakati, (2001). Manual on Small Earth Dam Construction. Kasisi Agricultural Training Centre in Association with Swedish Cooperative Centre.

[5] Petersen, N. E (2006). Water from Small Dams: A handbook for technicians, farmers and others on site investigations, designs, cost estimates, construction and maintenance of small earth dams. Danish International Development Assistance (Danida). Keneya.

[6] Onwuegbunam, D.O., Oyebode, M. A., Onwuegbunam N. E., Maikano, S.,and Waziri C. H. (2009). Sedimentation Assessment of a Small Reservoir at Afaka Forest Reserve, Kaduna, Nigeria. Journal of Environment and Earth Science. Vol.3, No.9.pp 80-115.

[7] Rooseboom, A and Lotriet, H. H. (1992). The new sediment yield map for southern Africa. Erosion and Sediment Transport Monitoring Programmes in River Basins (Proceedings of the Oslo Symposium, August 1992). IAHS Publ. no. 210.pp 98-118. 
An Assessment of Available Water for Livestock and Garden Irrigation in Dry Season for Subsistence Farmers in Zimba District

[8] Meehan, M.A Stokka G, Mostrom,M (2016). Livestock and Water Requirement. County Commissions, NDSU and U.S. Department of Agriculture Cooperating

[9] Chambers, R. (1988). Managing Canal Irrigation. Cambridge, Cambridge University Press.

Citation: C. Innocent. C, "An Assessment of Available Water for Livestock and Garden Irrigation in Dry Season for Subsistence Farmers in Zimba District", International Journal of Research Studies in Agricultural Sciences (IJRSAS), vol. 3, no. 9, p. 6, 2017. http://dx.doi.org/10.20431/2454-6224.0309003

Copyright: (C) 2017 Authors. This is an open-access article distributed under the terms of the Creative Commons Attribution License, which permits unrestricted use, distribution, and reproduction in any medium, provided the original author and source are credited. 